\title{
Hantavirus pulmonary syndrome in Brasilia periphery: a diagnostic challenge
}

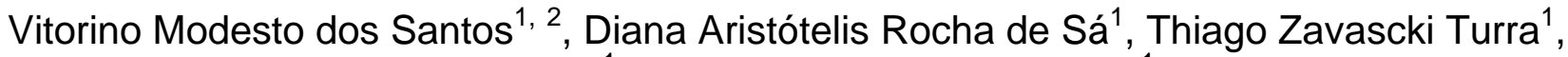 \\ Nancy Mendonça Ferreira Borges ${ }^{1}$, Ulisses Mariano Nascimento ${ }^{1}$, \\ Emanuel Adelino Medeiros Damasceno ${ }^{2}$
}

\author{
${ }^{1}$ Department of Internal Medicine from the Armed Forces Hospital (HFA), \\ Estrada do Contorno do Bosque s/n, 70630-900, Brasilia-DF, Brazil \\ ${ }^{2}$ Catholic University Medical Course, Brasília-DF, Brazil
}

\begin{abstract}
Background: Hantavirus pulmonary syndrome (HPS) is an emerging rodent-borne disease in the American continent, characterized by acute respiratory distress and a high case-fatality ratio. The present work describes a case of HPS, with favorable outcome, whose initial features were mistaken for leptospirosis or other less severe acute infections.

Methodology: The case of a 32-year-old male with an uneventful course of HPS is reported. He was inadvertently infected at work by exposure to a rodent-contaminated environment in Brasília, Federal District vicinity, during May 2008.

Results and Conclusions: Fever, headache and myalgia after exposure to a rodent-contaminated environment raised clinical suspicion. Noncardiac pulmonary edema, hydrothorax, neutrophilia with band forms $26 \%$, high hematocrit, thrombocytopenia, and elevated liver enzymes were observed. Leptospirosis and dengue were the main differential diagnoses because both pathogens are endemic in the area. Hantavirus IgM antibody-capture ELISA was positive, while tests for dengue, leptospirosis and yellow fever were negative.

The prognosis for HPS is ominous and misdiagnoses may increase mortality. Better chances of survival depend on prompt intensive care support. Reports of moderate or less typical cases can raise the suspicion index among primary care and hospital-based physicians about this uncommon but severe condition that often affects previously healthy young individuals from developing countries, and subjects who interact with rodent-infested environments in North America.

High awareness of HPS allowed successful management of the patient, even before establishing the diagnosis, by serological tests at the reference laboratory of the Ministry of Health. Clinical suspicion favored warning local health authorities about a new case of HPS.
\end{abstract}

Key Words: Brazil, Brasília, diagnosis; Hantavirus; Hantavirus pulmonary syndrome

J Infect Dev Ctries 2009; 3(8):639-643.

Received 21 March 2009 - Accepted 15 July 2009

Copyright $\odot 2009$ dos Santos et al. This is an open-access article distributed under the Creative Commons Attribution License, which permits unrestricted use, distribution, and reproduction in any medium, provided the original work is properly cited.

\section{Introduction}

Hantavirus pulmonary syndrome (HPS) is a rodent-borne disease emerging across the American continent. Wild rodents of the subfamily Sigmodontinae are the main reservoirs of dozens of hantavirus genotypes that have been described as agents of HPS in America [1]. They belong to the Bunyaviridae family and inhalation of aerosolized excreta of the infected rodents is the main cause of infection [2]. Interestingly, cases of person-to-person transmission of HPS have been described in Argentine and Chile [2,3].

Although interest in HPS has increased since 1993 with the Sin Nombre virus discovery in the Four Corners region of the United States [2,4,5], this syndrome has been scarcely reported and the global hantavirus infection rate is not well-known [2]. It is important to note that people from non-endemic areas may be infected during international travel, and hantavirus should be considered imported infectious agents in developed countries [6-8].

The hallmark of HPS is severe acute respiratory distress with public health burden [2,9]. However, primary care physicians and intensive care unit (ICU) professionals of non-endemic areas must be aware of patients with less obvious features of imported HPS [7,8]; otherwise, HPS may be under-diagnosed or misdiagnosed in developing and developed countries.

Based on an official Brazilian health report, four cases of HPS were confirmed in Brasilia-Distrito Federal (DF) in 2008. Although preliminary studies about prevalent rodent species and population rate infection have been done in Central Plateau (Goiás State and Brasilia-DF periphery) [1], the real 
Table 1. Comparative blood determinations during the evolution of HPS in a Brazilian male

\begin{tabular}{|c|c|c|c|c|c|}
\hline Parameters & *Day 2 & Day 4 & Day 5 & Day 6 & Day 7 \\
\hline $\mathrm{RC}\left(4.7-6.0 \times 10^{12} / \mathrm{L}\right)$ & 5.52 & 6.31 & 5.18 & 4.61 & 4.18 \\
\hline $\mathrm{Hb}(13.5-18 \mathrm{~g} / \mathrm{dL})$ & 15.2 & 17.2 & 14.4 & 12.8 & 11.4 \\
\hline Hematocrit $(42-52 \%)$ & 46.2 & 52.9 & 43.3 & 38.0 & 34.9 \\
\hline $\mathrm{WBC}\left(4-11 \times 10^{9} / \mathrm{L}\right)$ & 6.5 & 20.3 & 21.7 & 20 & 16.8 \\
\hline WBC percent & $2,65,1,0,22,10$ & $26,52,0,0,18,6$ & $18,65,2,0,10,5$ & $5,60,0,0,31,2$ & $0,60,2,0,27,11$ \\
\hline Platelets $(>150,000)$ & 183,000 & 55,000 & 64,000 & 112,000 & 168,000 \\
\hline PA $(70-100 \%)$ & 68 & 42 & 69 & 71 & 72 \\
\hline INR & 1.28 & 1.82 & 1.27 & 1.24 & 1.23 \\
\hline $\mathrm{Na}(135-145 \mathrm{mEq} / \mathrm{L})$ & 132 & 128 & 132 & 138 & 140 \\
\hline $\mathrm{K}(3.5-5.2 \mathrm{mEq} / \mathrm{L})$ & 3.9 & 4.7 & 5.5 & 5.0 & 4.2 \\
\hline $\mathrm{Cl}(95-108 \mathrm{mEq} / \mathrm{L})$ & 98.0 & 100.0 & 102.9 & 106.0 & 104.8 \\
\hline Urea $(10-50 \mathrm{mg} / \mathrm{dL})$ & 24.8 & 28.2 & 29.3 & 28.6 & 34.4 \\
\hline Creat $(0.7-1.3 \mathrm{mg} / \mathrm{dL})$ & 1.3 & 1.0 & 0.9 & 0.9 & 1.0 \\
\hline $\mathrm{AST}(<39 \mathrm{U} / \mathrm{L})$ & 22.4 & 55.6 & 181.2 & 266.8 & 173.6 \\
\hline ALT (< 42 U/L) & 26.3 & 40.9 & 143.3 & 306.4 & 275.6 \\
\hline Alb (3.8-4.4 g/dL) & 3.9 & 3.2 & ND & 3.3 & 3.5 \\
\hline LDH (100-190 U/L) & ND & 402 & 448 & 467 & 472 \\
\hline CK $(<171 \mathrm{U} / \mathrm{L})$ & 102.9 & 151.7 & 132.5 & 135.4 & 148.0 \\
\hline
\end{tabular}

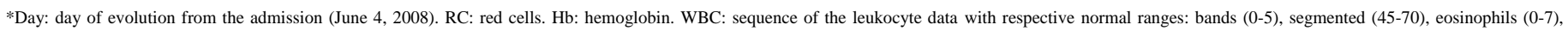
basophils (0-3), lymphocytes (20-50), monocytes (2-10); PA: prothrombin activity. Creat: creatinine. Alb: albumin. ND: not done.

magnitude of this emerging disease remains unclear. Here we report a less severe case of HPS, occurring in the periphery of a city with well-planned urbanization, in which HPS was initially mistaken for leptospirosis, a well-known endemic pathogen in the same area [10]. The authors also stress the possibility of imported infections, with less typical clinical features and increased diagnostic difficulties, from developing countries affecting people of industrialized areas.

\section{Case Report}

In June 4 2008, a 32-year-old male presented with high fever, chills, frontal headache, myalgia, and asthenia four weeks after participating in professional training activities in a non-degraded rural area at the periphery of Brasília-DF. Analysis of blood tests following his admission in the Emergency Department showed leukocytosis and high band count, lowering platelets, elevated creatinine, and rising levels of AST, ALT and LDH (Table 1), while the capillary fragility test was negative. Urinalysis and EKG were unremarkable. Because of the suspicion of anicteric leptospirosis, he was started on a course of intravenous penicillin. Two days after hospitalization, he complained of intense respiratory distress and fine rales were heard in both lung fields. Chest radiography studies disclosed bilateral lung interstitial and alveolar parenchymal infiltrates, with a normal heart (Figures 1A to 1C). He was sent to the intensive care unit with a suspected case of HPS and/or leptospirosis. The use of crystalline penicillin G (12 million units IV daily) and correction of hydroelectrolytic disturbances (Table 1) were followed by clinical improvement, despite the development of bilateral pleural effusion (Figures 1D and $1 \mathrm{E})$. He was then transferred to the internal medicine ward on the fourth day of admission. Lung infiltrates and pleural effusion disappeared on the tenth day (Figure 1F). Pleural fluid showed 78 leukocytes and 3,397 red cells $/ \mathrm{mm}^{3}$ (with hematocrit lower than 1 percent), protein $2.6 \mathrm{~g} / \mathrm{dL}, \mathrm{LDH} 152$ $\mathrm{U} / \mathrm{L}$ and glucose $122 \mathrm{mg} / \mathrm{dL}$. Diagnosis tests for leptospirosis (IgM by Enzyme immunoassay) and yellow fever (IgM by MAC-ELISA) showed negative results in the first week and in the convalescent phase of the disease. Negative tests for dengue were obtained on June 9 (IgM and $\operatorname{IgG}$ by Immunochromatography), and June 26 (IgM by MAC-ELISA). Investigations for tuberculosis and malaria were negative, as were the routine blood cultures. The HPS diagnosis was established by reagent $\operatorname{IgM}$ antibody-capture ELISA in the first week of disease, and confirmed two weeks later in the Instituto Adolpho Lutz reference laboratory of the Brazilian Ministry of Health for the study of hantaviruses. Recombinant antigen of ANDES hantavirus from the Instituto Malbrán, Buenos Aires, Argentina, was utilized following the analysis protocol of the Centers for Disease Control, Atlanta, USA (Instituto Adolpho Lutz, São Paulo-SP). RTPCR was not performed in the present case; however, 
Figure 1.

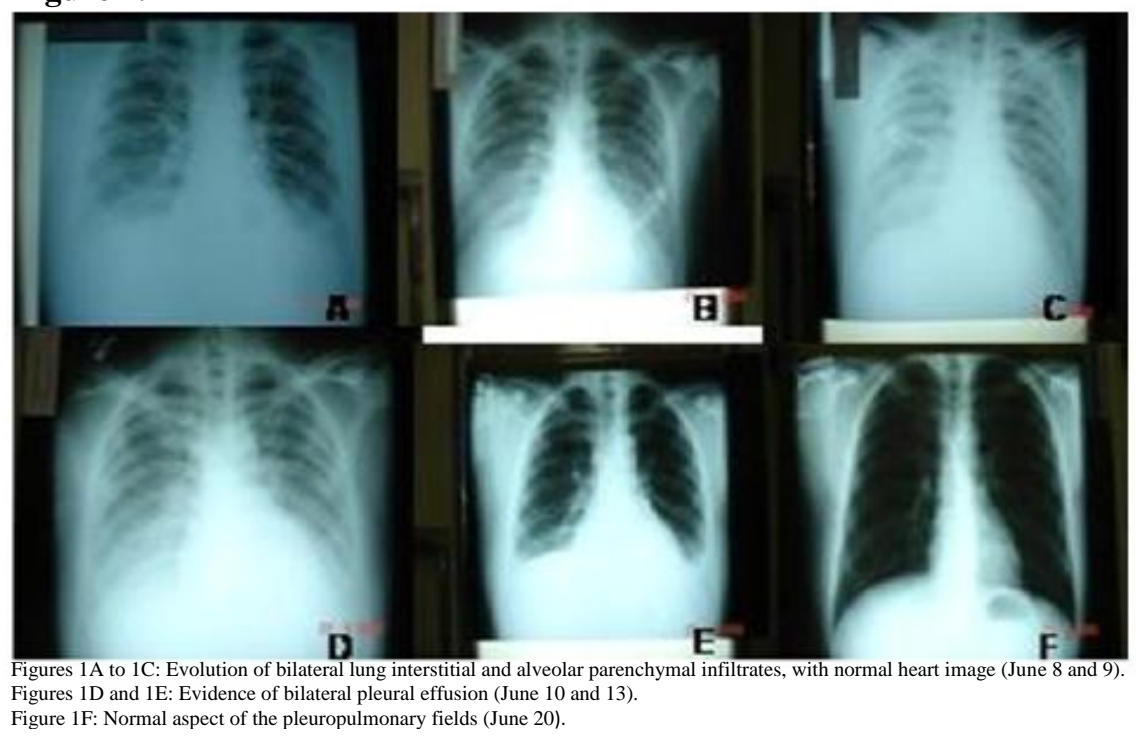

the genotype Araraquara has been found in samples of rodents and humans from the Brasília-DF area and the State of Goiás region [1].

In conformity with the Hospital Research Ethical Committee (CAAE - 0001.0.376.000-09), the patient signed the respective informed consent. He was discharged to his home without any complaints 20 days after admission. One month later, he was able to perform normal professional activities with no restriction.

\section{Discussion}

The first suspicion of HPS in Brazil was reported in 1995 [5] in a patient from a rural area of Triângulo Mineiro; however, the diagnosis could not be established due to lack of laboratory support. The first confirmed cases of HPS in Brazil occurred in a rural zone of Juquitiba-SP, and were described in 1997 [11]. From 1993 to 2007, 177 HPS cases (near $20 \%$ of the total of cases) occurred in the Brazilian Central region, with a $44.5 \%$ case-fatality rate in areas with the Araraquara virus (ARAV). Necromys lasiurus, a Sigmodontinae rodent enzootic in the Central Plateau, constitutes reservoirs of ARAV [1]. Diverse agents of HPS, including Anajuba virus, Castelo dos Sonhos virus, Juquitiba virus, and Laguna Negra-like virus, have been detected in Brazilian patients from other regions [1,2].

Brasília-DF is situated in the Brazilian Central Plateau $\left(15^{\circ} 30^{\prime}-16^{\circ} 03^{\prime}\right.$ south and $47^{\circ} 18^{\prime}-48^{\circ} 17^{\prime}$ west; altitude 750-1,350 meters; and approximately $5,800 \mathrm{~km}^{2}$ ), surrounded by a savanna-like ecosystem, called "cerrado", where several wild mammals live, including Sigmodontinae rodents [1]. The regional ecosystem has also favored the occurrence of leptospirosis, yellow fever, and dengue. Interestingly, the first reported cases of human leptospirosis in areas neighboring Brasília-DF were diagnosed following an epidemic of yellow fever in the same areas [12].

As a whole, the clinical and epidemiological data of this patient correspond to descriptions of moderate or less severe cases of HPS [1,13], mainly because the treatment of pulmonary edema did not require endotracheal intubation and mechanical ventilation [14]. He was a previously healthy young male whose professional activities involved recent contact with an environment contaminated by rodent reservoirs of viral agents of the syndrome. Classical features such as non cardiogenic lung edema, bilateral pleural effusion, and accentuated neutrophilia with a very high band count (26\%) were observed [2]. However, as often occurs in the initial steps of viral infection investigations in general [9], the early differential diagnosis constituted a real challenge in the present case (see Box 1), especially before receiving the results of the serologic tests for leptospirosis and viral infections performed at reference laboratories of the Brazilian Health Ministry. Indeed, leukocytosis and neutrophilia, plus high levels of creatinine and aminotransferases, in addition to the patient's fast improvement after use of penicillin, strongly suggested leptospirosis. Moreover, leptospirosis [4] or dengue likely can be associated in patients with HPS in endemic areas for both pathogens, such as the Brasília-DF periphery region. 


\author{
Box 1. HPS differential diagnosis - Tests utilized and \\ manufacturers \\ (ANDES virus) Hantavirus IgM capture by ELISA \\ (Instituto Adolfo Lutz, São Paulo-SP, Brazil). \\ Dengue virus IgM/IgG by Immunochromatography \\ (WAMA Diagnóstica, São Carlos-SP, Brazil). \\ Dengue virus IgM/IgG by MAC-ELISA (Instituto Evandro \\ Chagas, Belém-PA, Brazil). \\ Yellow fever IgM/IgG by MAC-ELISA (Instituto Evandro \\ Chagas, Belém-PA, Brazil). \\ Leptospirosis IgM/IgG by ELISA (FIOCRUZ Bio- \\ Manguinhos, Rio de Janeiro-RJ, Brazil).
}

Pleural fluid samples obtained eight days after admission showed the serum protein ratio more than 0.5 and $\mathrm{LDH}$ greater than two thirds of the upper normal limit, as often occurs [15]. Elevated red cell count, such as that found in the pleural fluid of this patient, has not been described in HPS typical cases [15], but could be associated with blood contamination by trauma during thoracocentesis. The high creatinine level found in the first analysis was probably due to pre-renal mechanisms. As HPS rarely affects the kidneys [2], this phenomenon could be mistaken as a diagnostic clue for the hantavirus hemorrhagic fever with renal syndrome (HFRS); however, in spite of lowering platelets count, the hemorrhagic features were absent. Although antibodies to hantaviruses responsible for this syndrome have been detected in people and rodents from northern, northeastern, southern and southeastern regions of Brazilian [16,17], human cases of HFRS have never been described in the Brazilian Central Plateau. Moreover, renal disorders may develop in patients with HPS, and should merit further studies [18,19]. The occurrence of hyponatremia coexistent with the most serious symptoms and abnormal laboratory parameters during the first days of disease is noticeable. This phenomenon has been frequently observed in HPS and may have no correlation with the amount or composition of the administered fluids, or with renal function [18]. In fact, hyponatremia can be associated with hypoalbuminemia due to acute phase response and capillary leak syndrome [14,20]. Elevated hematocrit $(52.9 \%)$ and low platelets $\left(55,000 / \mathrm{mm}^{3}\right)$ in the second day of admission raised the hypothesis of dengue; in addition, hydrothorax can be due to severe dengue with capillary leakage [21]. Yellow fever, malaria and sepsis were also offered as possible diagnoses, but these conditions were ruled out by analysis of the clinical features and complementary data.

The high case-fatality rate (near 40\%) observed in HPS [1] has been correlated with the extension of the pulmonary radiographic changes [22]. In spite of the radiographic findings in both lungs, this patient evolved rapidly to heal without complications after correction of mild hydroelectrolytic disturbances and the benefits of routine ICU support. This phenomenon may be due to differences of severity between infections caused by Brazilian lineages of hantavirus [1]. Phylogenetic data indicate that in the Central Plateau the main groups of hantavirus are very similar to ARAV [23]. Although ARAV strains are more frequently associated with higher virulence and severe manifestations, many infections caused by this virus are benign [1]. Ribavirin was not considered for use in the present case because of the current lack of support data and because of the non severe clinical manifestations [24].

Data for suspicion of HPS include fever, headache and myalgia after exposure to rodent-contaminated environments. As the prognosis for HPS is ominous, better chances for survival depend on early suspicion for the diagnosis and appropriate intensive care resources [2,6,9]. Additional concerns are misdiagnosis involving atypical cases, and the possibility of inter-human transmission $[2,3]$.

Reports of less typical cases of HPS can increase the awareness of primary and hospital-based professionals, including ICU physicians [9], about this emerging condition that may be nonspecific, unrecognized [2,13], misdiagnosed [25] and underreported. Diagnostic suspicion is necessary for specific diagnosis of HPS by serological tests and the subsequent warning to local health authorities.

\section{References}

1. Figueiredo LTM, Moreli ML, de Souza RLM, Borges AA, de Figueiredo GG, Machado AM, Bisordi I, Nagasse-Sugara TK, Suzuki A, Pereira LE, de Souza RP, de Souza LTM, Braconi CT, Harsi CM, Zanotto PMA, and the Viral Diversity Genetic Network Consortium (2009) Hantavirus pulmonary síndrome, Central Plateau, Southeastern, and Southern Brazil. Emerg Infect Dis 15: 561-7.

2. Bi Z, Fomenty PBH, Roth CE (2008) Hantavirus infection: a review and global update. J Infect Developing Countries 2: 323.

3. Martinez VP, Bellomo C, San Juan J, Pinna D, Forlenza R, Elder M, Padula PJ (2005) Person-to-person transmission of Andes virus. Emerg Infect Dis 11: 1848-53.

4. Santos VM (1994) Leptospirose e síndrome pulmonar por Hantavírus. Rev Ass Med Bras 40: 225.

5. Santos VM (1995) Doença respiratória aguda pelo Hantavirus four corners. Rev Soc Bras Med Trop 28: 59. 
6. Castillo C, Nicklas C, Mardones J, Ossa G (2007) Andes Hantavirus as possible cause of disease in travellers to South America. Travel Med Infect Dis 5: 30-4.

7. Murgue B, Domart Y, Coudrier D, Rollin PE, Darchis JP, Merrien D, Zeller HG (2002) First reported case of imported Hantavirus pulmonary syndrome in Europe. Emerg Infect Dis 8: 106-7.

8. Reynolds S, Galanis E, Krajden M, Morshed M, Bowering D, Abelson W, Kollmann TR (2007) Imported fatal hantavirus pulmonary syndrome. Emerg Infect Dis 13: 1424-5.

9 Stollenwerk N, Harper RW, Sandrock CE (2008) Bench-tobedside review: rare and common viral infections in the intensive care unit - linking pathophysiology to clinical presentation. Crit Care 12: 219 Epub 2008 Jul 17. doi: 10.1186/cc 6917

10. Santos VM, Santos BG, Montechi NV, John IA (1979) Leptospirose - primeiro relato de casos autóctones de Brasília Rev Pat Trop 81: 15-33.

11. Silva MV, Vasconcelos MJ, Hidalgo NTR, Veiga APR, Canzian M, Marotto PCF, Lima VCP (1997) Hantavirus pulmonary syndrome. Report of the first three cases in São Paulo, Brazil. Rev Inst Med Trop São Paulo 39: 231-4.

12. Santos VM, Piva N, Campos ALR, Lavor AC (1974) Leptospirose - relato dos dois primeiros casos ocorridos em Goiás. Rev Pat Trop 3: 235-49.

13. Campos GM, Sousa RLM, Badra SJ, Pane C, Gomes UA, Figueiredo LTM (2003) Serological survey of hantavirus in Jardinópolis county, Brazil. J Med Virol 71: 417-22.

14. Xiao R, Yang S, Koster F, Ye C, Stidley C, Hjelle B (2006) Sin Nombre viral RNA load in patients with hantavirus cardiopulmonary syndrome. J Infect Dis 194: 1403-9.

15. Bustamante EA, Levy H, Simpson SQ (1997) Pleural fluid characteristics in hantavirus pulmonary syndrome. Chest 112 : 1133-6.

16. LeDuc JW, Smith GA, Pinheiro FP, Vasconcelos PFC, Rosa EST, Maiztegui JI (1985) Isolation of a Hantaan-related vírus from Brazilian rats and serologic evidence of its widespread distribution in South America. Am J Med Trop Hyg 34: 8105.

17. Iversson LB, da Rosa AP, Rosa MD, Lomar AV, Sasaki MG, LeDuc JW (1994) Infecção humana por Hantavirus no Sul e Sudeste do Brasil. Rev Assoc Med Bras 40: 85-92.
18. Pergam AS, Schmidt DW, Nofchissey RA, Hunt WC, Harford AH, Goade DE (2009) Potential renal sequelae in survivors of hantavirus cardiopulmonary syndrome. Am J Trop Med Hyg 80: 279-85.

19. Castillo C, Naranjo J, Sepúlveda A, Ossa G, Levy H (2001) Hantavirus pulmonary syndrome due to Andes vírus in Temuco, Chile: clinical experience with 16 adults. Chest 120: 548-54.

20. Ferreira da Cunha D, Pontes Monteiro J, Modesto dos Santos V, Araújo Oliveira F, Freire de Carvalho da Cunha S (2000) Hyponatremia in acute-phase response syndrome patients in general surgical wards. Am J Nephrol 20: 37-41.

21. Guzmán MG, Kourí G (2002) Dengue: an update. Lancet Infect Dis 2: 33-42.

22. Boroja M, Barrie JR, Raymond GS (2002) Radiographic findings in 20 patients with hantavirus pulmonary syndrome correlated with clinical outcome. Am J Roentgenol 178: 15963.

23. Melo-Silva CR, Maranhão AQ, Nagasse-Sugahara TK, Bisordi I, Susuki A, Brigido MM (2009) Characterization of hantavirus circulating in Central Brazil. Infect Genet Evol 9: 241-7.

24. Mertz GJ, Miedzinski L, Goade D, Pavia AT, Hjelle B, Hasbanger CO, Levy H, Koster FT, Baum K, Lindemulder A, Wang W, Riser L, Fernandez H, and Whitley RJ, for the Collaborative Antiviral Study Group (2004) Placebocontrolled, double-blind trial of intravenous ribavirin for the treatment of hantavirus cardiopulmonary syndrome in North America. Clin Infect Dis 39: 1307-13.

25. Rivers MN, Alexander JL, Rohde RE, Pierce JR Jr (2009) Hantavirus pulmonary syndrome in Texas: 1993-2006. South Med J 102: 36-41.

\section{Corresponding Author}

Professor Vitorino Modesto dos Santos

SMPW Quadra 14 Conjunto 2 Lote 7 Casa A, 71.745-140, Brasília-DF, Brazil

Tel.: 55-61 33802666. Fax: 55-61 32331599.

E-mail: vitorinomodesto@gmail.com

Conflict of Interest: No conflict of interest is declared 